\title{
Foraging behaviour and diet selection in domestic herbivores
}

\author{
Sophie Prache ${ }^{\mathrm{a} *}$, Iain J. Gordon ${ }^{\mathrm{b}}$, Andrew J. Rook ${ }^{\mathrm{c}}$ \\ ${ }^{a}$ Inra, Centre de Clermont-Ferrand/Theix, 63122 Saint-Genès-Champanelle, France \\ ${ }^{\mathrm{b}}$ MLURI, Craigiebuckler, Aberdeen, AB9 2QJ, UK \\ ' IGER, North Wyke, Okehampton, EX20 2SB, UK
}

(Received 28 May 1998; accepted 23 September 1998)

\begin{abstract}
Foraging behaviour and diet selection determine both the nutrient intake by the animals and their impact on the vegetation. They are therefore of importance for animal and vegetation management. Animals exploit the heterogeneity of resources through selective grazing, choosing a diet of better quality than the average vegetation on offer. Recent increased effort has been made to develop models of the grazing process supported by theory, which should facilitate generalisation and application to a broad range of situations. Foraging involves the interactions between the characteristics of the animal and the characteristics of food in the environment. We review some of the animals' foraging decisions within the vegetation, morpho-physiological, digestive and behavioural constraints they face. The determinants of foraging behaviour and diet selection remain, however, somewhat obscure and a matter of debate. The complexity of the animal/vegetation interactions have prompted the development of simple experimental approaches, and further research is needed to extrapolate these to larger spatio-temporal scales. (C) Elsevier / Inra
\end{abstract}

\section{foraging behaviour / dietary choices / grazing}

Résumé - Comportement d'ingestion et choix alimentaires au pâturage chez les herbivores domestiques. Le comportement d'ingestion et les choix alimentaires au pâturage conditionnent l'ingestion de nutriments par les animaux et leur impact sur la végétation. Une meilleure compréhension de leurs déterminants est donc importante pour gérer la dynamique des systèmes pâturés. Les animaux exploitent l'hétérogénéité des ressources en pâturant de manière sélective et en choisissant un régime de meilleure qualité que ce qui leur est offert. Un effort récent a été fait pour développer une approche hiérarchiséc du processus de pâturage, étayée par des bases théoriques, afïn de dégager des lois générales applicables à des situations variées. Le comportement d'ingestion et les choix alimentaires résultent de l'interaction entre les caractéristiques des animaux et celles de la végétation offerte. Cette revue présente certaines décisions des animaux face aux contraintes qu'ils rencontrent, qui sont liées à la végétation, à lcurs caractéristiques morpho-physiologiques propres, ou au temps dont

\footnotetext{
* Correspondence and reprints

Tel.: (33) 0473624063 ; fax: (33) 04736241 18; e-mail: prache@clermont.inra.fr
} 
ils disposent pour pâturer. Les déterminants du comportement d'ingestion et de choix demeurent cependant encore en partie mal compris. La complexité des interactions animal/végétation a conduit à d'abord privilégier des approches expérimentales simples, le challenge principal étant maintenant l'intégration à des échelles de temps et d'espace plus larges. (O) Elsevier/Inra

\section{comportement / ingestion / choix alimentaires / pâturage}

\section{INTRODUCTION}

Foraging behaviour and diet selection are of major importance within grazing systems because they determine the nutrient intake of the animals as well as the location and intensity of animals' impact on the vegetation. A better understanding of their determinants is therefore fundamental to animal and vegetation management. Animals exploit the heterogeneity of resources through selective grazing, choosing a diet which is of better quality than the average vegetation on offer $[31,46]$. Intake and the effects on the vegetation are hence mediated by animals' selectivity.

The determinants of foraging decisions remain obscure, since many studies are largely descriptive, failing to provide generality. Recently, increased effort has been made to develop models of the grazing process supported by a sound theoretical basis. This approach should allow a better understanding of the determinants of animals' foraging decisions and their impact on the vegetation, and should facilitate generalization of research results to a broader range of situations.

\section{REPRESENTATION} OF THE GRAZING PROCESS AND THEORETICAL BASES OF FORAGING BEHAVIOUR

\subsection{Representation of the grazing process}

Foraging decisions occur at various spatio-temporal scales. Spatial heterogeneity is difficult to envisage, because it must be defined from the animals' point of view. Laca and Ortega [34] proposed six scales of organisation, defined by specific behaviours, from bite to home range. We focus in this paper on the smaller scales, i.e., from bite to patch selection, whereas the paper by Bailey et al. (this issue) deals with larger scales. These different scales are nevertheless closely related.

A patch is defined as a spatial aggregation of bites over which instantaneous intake rate (IIR) remains relatively constant [29]. Two adjacent patches are considered to be distinct when the variability of IIR between the two patches is sufficient compared with intra-patch variability. There still remains the problem of how to fix a threshold.

When an animal begins to eat, it may be seen as selecting a feeding site, a patch in the site, within which bites are selected. Selection of bites within this patch continues as long as IIR remains above a certain threshold [5]. When IIR falls below this threshold, the animal selects a new patch; and when acceptable patches in the site become scarce, a new feeding site is selected. This representation of the grazing process enables foraging behaviour to be formalised in terms of a hierarchy of scales where animals make decisions and integrates these over different spatio-temporal levels [34].

\subsection{Theoretical bases}

There are two main ways of looking at foraging decisions. Synthetic (or ultimate) approaches assume that animals organise 
their behaviour towards an objective, analytical (or proximate) approaches explain behaviours from cause-effect relationships.

The basic axiom of the main synthetic approach, Optimal Foraging Theory (OFT), states that present-day animals forage optimally as a result of natural selection because more efficiently foraging animals have greater reproductive output (fitness) [32, 33]. Fitness maximisation has often been translated into efficiency of foraging, which, for practical reasons has often been equated with short-term dry matter intake rate. Recent models include instead the maximisation of fitness [39]. An alternative to the OFT hypothesis, the principle of 'satisficing' hypothesises that a behavioural option may be taken, not only when it is optimal, but when it is sufficient to overcome some threshold requirement for the animal [64]. This gives a problem as to how to define a satisfaction threshold if one wants to predict foraging behaviour. Analytical approaches stress rather on cause-effect proximate relationships in the determinism of foraging behaviour, such as sensory stimuli $[1,50]$, post-ingestive feedbacks resulting from previous choices [48] and dietary experiences $[12,18]$.

Synthetic-ultimate and analytical-proximate approaches should be perceived as complementary rather than exclusive [33]. For example, if OFT stresses the importance of natural selection in the determinism of behaviour, it can not exclude the importance of short-term dietary experiences. Optimisation-based predictions should therefore include animals' dietary experiences. The difficulty in dissociating the two approaches is well illustrated by the question posed by Illius et al [30]: do animals eat a plant species faster because they prefer it (sensory stimulus) or do they prefer it because they eat it faster (optimisation of behaviour)? In contrast, optimisation and satisficing assumptions do seem mutually exclusive.

Optimisation is an elegant approach because it is a functional synthesis of forag- ing behaviour and it enables quantitative predictions $[42,39,62]$. However, it may be a simplified representation of reality and the basic theoretical axiom has generally been simplified. Moreover, there are still few experimental tests of this theory, and they have generally not completely validated it $[2,10,30]$. This had led to inconclusive explanations, such as the necessity for the animal to sample its environment [10], constraints on the animal's ability to evaluate the profitability of different behavioural options [30], search for a balance of nutrients and dilution of toxins [28, 37, 43, $63]$. These factors do not deny the optimisation principle, but underline the importance of constraints that may be difficult to assess $[39,63]$.

The weakness of early optimisation models lay in the extrapolation from small to larger spatio-temporal scales. These models were developed to describe short-term foraging behaviour. As spatio-temporal scales become larger, foraging behaviour becomes more complex to describe and understand, as it integrates trade-offs with other processes and behaviours. The stochastic dynamic programming approach proposed by Newman et al [39] is a first attempt of integration. Further steps are needed: i) integration of digestive processes, ii) refinement of constraints and the animal's abilities to face them, iii) integration of interactions of foraging with other motivations such as shelter, social interactions and predator avoidance.

\section{HOW DO ANIMALS RESPOND TO THEIR FORAGING ENVIRONMENT?}

Foraging involves the interactions between the characteristics of the animals and the characteristics of food in the environment. We consider some of the animals' foraging decisions within the vegetation, morpho-physiological, digestive, and behavioural constraints they face. 


\subsection{How do vegetation characteristics influence foraging decisions?}

In the light of the representation of grazing process proposed earlier, we discuss how vegetation characteristics influence animals' foraging decisions, including the bites prehended on the patch, the length of time to graze a patch before moving to another, and the further choice of a new patch.

\subsubsection{Patch level}

Instantaneous intake rate on the patch is determined by the mass of the bite (BM) and the time required to perform it $(\mathrm{T})$. Time per bite may be split into two components $\mathrm{T}=\mathrm{a}+\mathrm{bBM}$, with $\mathrm{a}=$ prehension time, and $\mathrm{bBM}=$ mastication time. This functional representation, based on the time budget concept, considers the animal as subject to two constraints: i) the time required to prehend and sever a bite, which is independent of bite mass; and ii) the time required to masticate the harvested material, which is constrained by bite mass $[38,44,47]$ and varies with plant species [38]. Bite mass is determined by the ease with which the sward can be gathered into the mouth and sheared; these determinants have been reviewed by Prache and Peyraud [45]. On vegetative swards, sward height and bulk density are the major determinants of bite mass and IIR $[2,3,35]$. On complex swards, bite mass is affected by the presence of 'barrier' components in the sward such as stems and dead material. Green leaf mass per unit area has been shown to be the best predictor of bite mass and IIR across different phenological stages of the sward $[19,44,47]$. However, sward height or green leaf mass per ha do not take into account all the factors involved, because they are respectively one- or twodimensional descriptors, while bites are taken in three dimensions [61]. The relationship between IIR and sward structure is a saturation curve, which is easily derived from the relationships described above [44, $47,57]$.

\subsubsection{Patch departure}

Forage depletion in the patch and perception or expectation of intake opportunities in other patches will motivate the animal to move on. The animal has to make a tradeoff between continuing to graze a patch where it is experiencing diminishing marginal rewards, and moving to another patch, thereby incurring a time cost. If the animal seeks to maximise intake rate, the marginal value theorem (MVT, [5]) predicts that the animal will leave the patch when intake rate within the patch equals the average intake rate for the whole environment. Demment et al. [10] and Laca et al. [36] have globally validated MVT, but Bazely [1] and Roguet [52] observed a longer residence time than predicted by MVT.

\subsubsection{Multi-patch level}

Patch choice may be influenced by factors such as vegetation characteristics, distance to water, climate or shelter, social and predation factors. Considering vegetation characteristics, two situations may be distinguished: i) those where the animal can express its preference; i.e. can graze the preferred patch without having to search; and ii) those where choices are affected by a cost of searching.

When searching costs are negligible, for example on a feeding site which offers easily found discrete patches, animals generally prefer patches where they can eat rapidly $[2,10,13,30]$, i.e. they will concentrate grazing on patches that offer greatest energy intake rate potential. This selective behaviour allows the animal to increase its rate of food intake [36]. However, preference is not absolute and intake rate is often less than optimisation predicts. For example, on a field consisting of adjacent monocultures of $6 \mathrm{~cm}$ tall grass and clover, the proportion of clover in the diet of sheep is only about $70 \%$, even though sheep generally eat clover faster than grass [38]. 
Why do animals express partial preference and choose mixed diets? In the shortterm, the necessity for the animal to consume the different patches to evaluate their profitability, the difficulty or a low interest by the animal in discriminating, and discrimination errors, have been proposed as explanations [30]. Actually, choice between patches depends on the ability of the animal to discriminate between patches [30, 36]. At a daily scale basis, diurnal pattern in preferences, search for a balance of nutrients and digestive constraints have been proposed as explanations of partial preferences and mixed diets $[39,63]$.

Preference for a plant species is sensitive to its relative height. Animals may trade-off quality for quantity and switch to the less-preferred item, when greater benefit is obtained on it $[4,24,25,46]$. If one assumes that animals seek to maximise intake rate, the switch to the less-preferred patch may be predicted from potential intake rate on each patch. On swards containing reproductive undergrazed patches in a vegetative grazed background, our data [47] lead us to predict that, if using optimality rules, animals should switch to reproduc- tive patches when the green leaf mass on vegetative patches reaches $300 \mathrm{~kg} \cdot \mathrm{DM} \mathrm{ha}{ }^{-1}$, i.e. $9 \mathrm{~cm}$ height (figure 1). This result is in agreement with the descriptive observations of Dumont et al [15]. However, animals may also make a trade-off between biomass and digestibility, i.e. short-term intake rate and long-term intake rate, because of digestive constraints. For example, wapitis offered choices between 2, 4, 6, 8 and 10 weeks regrowth patches preferred patches of medium biomass and quality (4-week regrowth), rather than better quality but lower biomass patches or higher biomass but lower quality patches [65].

In natural conditions, there are often additional constraints of searching for preferred patches, which may limit intake rate. These constraints are determined by total herbage availability, relative horizontal abundance of preferred species and their spatial distribution. They make the environment more difficult for the animal to perceive and increase the probability to consume lesspreferred but easier to reach food patches [7]. In order to increase encounter with preferred patches, the animal may develop search strategies, such as walking faster,

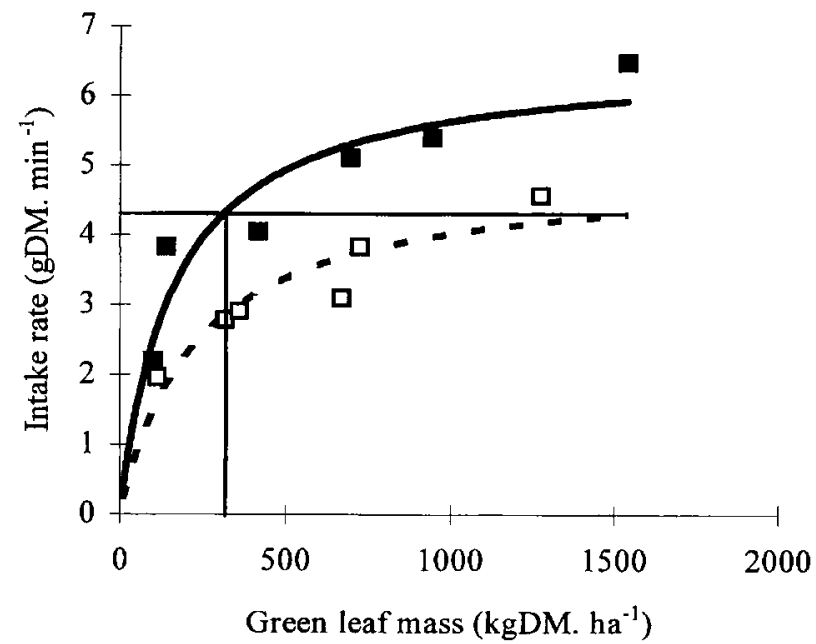

Figure 1. Prediction of diet choices based on dry matter intake rate maximisation: an example on swards containing reproductive patches in a background of vegetative patches (from Prache et al. [47]). 
increasing daily grazing time $[47,53,55$, 57], learning about the location of food and using its spatial memory together with visual cues $[16,17,34]$. The cost of searching is difficult to assess. Indirect indicators may be used, such as the animal's degree of selectivity expressed as the difference between diet and sward composition, intake per distance walked and proportion of bites encountered removed $[34,47,53]$. Prache et al [47] quantified a positive relationship between the cost of time needed to obtain a unit of herbage and the animal's degree of selectivity.

The proportion of a preferred food item in the diet is generally related to its proportion in the sward, i.e., there is a tendency towards frequency-dependent selection $[6,46]$. A decrease in horizontal availability may affect encounter rate. For example, when grassclover swards contained $20 \%$ clover by ground area, sheep spent $44 \%$ of their grazing time on clover vs. 73 and $67 \%$ when the clover represented 50 and $80 \%$ of the area [43].

The scale of patchiness may have marked effects on animal's foraging decisions, although it has not, as yet, received much attention. Two scales of patchiness may involve searching costs: small-scale, with constraints due to selection of preferred from less-preferred food items, and larger scale with constraints due to moving and locating preferred patches (see also the paper by Bailey et al. in this issue).

Fine mixtures reduce the opportunity for selection whereas large patches offer maximum opportunity for selection. For example, sheep grazing grass/clover swards select more clover when species are offered in separate strips than in an intimate mixture [6]. Gordon et al. [23] observed no differences in the diet selected by sheep on 4 dispersions of clover and grass, but higher intake rate on larger patches.

Large-scale heterogeneity may impose a constraint on moving to reach preferred patches, which may affect intake rate [36], unless moving time is completely devoted to mastication. It may also impose constraints on the visual perception of alternative patches and spatial knowledge [34]. Use of visual cues may in this case enable the animals to increase efficiency of search and intake rate [34].

\subsection{How do animal characteristics influence foraging decisions?}

Morpho-physiological characteristics, animal state, dietary experiences and social environment influence foraging abilities and decisions of animals. Some of these variables integrate the effects of previous foraging decisions. A hierarchical approach may hence be useful in integrating smallscale processes into larger scale ones [34, 39].

\subsubsection{Morphological characteristics}

Herbivores' body mass induces differences in energy requirements, ingestive and digestive capacities. These characteristics are presumed to explain most betweenspecies differences in foraging behaviour. On the other hand, because of their digestive system, horses have a great ability to exploit and control low-quality swards [14].

The efficiency of grazing depends on incisor arcade breadth, on the force the animal can exert when biting, and in cattle, on the degree of protusion of the tongue. General relationships between morphological characteristics and efficiency of grazing have been derived from data on various ruminant species. Shipley et al [56] estimate maximum short-term dry matter intake rate as $0.63 \mathrm{~W}^{0.71}$ ( $\mathrm{W}$ being animal's liveweight). Maximum bite weight increases with body size, scaling with $\mathrm{W}^{0.67}$ to $\mathrm{W}^{0.76}[11,26$, 56]. The rate of food processing in the mouth scales with $\mathrm{W}^{0.70}$ [56]. It has been suggested that, because of larger molar surface area, large animals may achieve similar particle size reduction as small ones with 
a lower mastication time [42]. Morphological differences induce differences in maximum bite area, rather than in bite depth, which is similar for cattle, sheep and goats, about $35 \%$ of sward height $[22,41]$. Mouth size increases with body mass. From data on various ruminant species, Illius and Gordon [27] proposed the following equation: incisor arcade breadth $(\mathrm{IAB}, \mathrm{mm})=8.6 \mathrm{~W}^{0.36}$. Taylor et al [58] proposed a greater allometric constant for cattle than sheep $\left(\mathrm{IAB}, \mathrm{mm}=9.84 \mathrm{~W}^{0.33}\right.$ for cattle, $8.44 \mathrm{~W}^{0.33}$ for sheep).

Sward structure and animal body mass interact, bite mass increasing faster with sward height for larger animals. This is explained by allometric relationships of bite area with sward structure $[11,27]$. On short swards, where only a narrow band of tillers can be prehended, bite area is determined by incisor arcade breadth (proportional to $\mathrm{W}^{0.33}$ to $\mathrm{W}^{0.36}$ ); on tall swards, bite area equals the product of incisor arcade breadth and mouth gape (assumed to equal to incisor arcade breadth), hence it increases proportionally with $\mathrm{W}^{0.67}$ to $\mathrm{W}^{0.76}$ [22]. Consequently, large animals are handicapped on short swards, where intake per bite increases more slowly with body mass than energetic requirements [27].

The energetic requirements of herbivores increase proportionally to $\mathrm{W}^{0.75}$, whereas gut volume increases linearly with W [9]. Hence, small animal species have to select better quality forages than large species, as the ratio of energetic requirements to gut volume is greater $[8,9]$. Moreover, small animal species are less efficient at digesting rough forages because of the shorter residence time of material in the rumen [14]. Differences in digestive physiology may also explain dietary differences between species of the same live weight [29]. Cattle also have a greater preference for rough forages than do sheep [15].

The shape of the incisor arcade also determines the ability to select between food items, which is greater for sheep than for cattle [21]. Hence, large animal species may be handicapped when accessibility of the preferred food items is poor; in this case, the quality of the diet selected by cattle may be much lower than that selected by sheep. Consequently, heterogeneity of the vegetation in a sward may change differently depending upon the body size of the animal species that grazes it, because of the different impact on colonising plant species at the boundaries of patches [29].

\subsubsection{Animal state}

The animal is able to use its behaviour as a flexible means to face physiological constraints. Actually, some volitional control of intake rate exists, as shown by experimental data relating foraging decisions to animal state.

After a period of food deprivation, the animal is able to increase its rate of food intake $[37,47]$, by increasing bite mass [37, 47], and/or decreasing time taken to masticate each unit of DM [33]. Nevertheless, fasting is hypothesised to reduce discrimination between food items. For example, although intake rate was higher on clover, Newman et al [37] observed that fasted sheep ate a higher proportion of grass than unfasted animals when offered adjacent patches of grass and clover.

The animal's physiological stage is responsible for great variation in requirements. Lactating animals achieve a greater intake than dry animals essentially through an increase in grazing time; hence, time available to forage may be an important constraint. Animals seem able to adapt their behaviour by grazing more efficiently. A high-producing animal may take heavier bites and spend less time per bite by choosing to reduce mastication rate in favour of prehension biting rate [44]. Moreover, the model of Newman et al [39] predicts that lactating ewes eat more clover and less grass than dry ewes, when offered a choice between the two herbage species. However, 
when the animal has to search for preferred food, time available to forage is likely to reduce its selectivity, but this has not been experimentally tested.

There is evidence for a diurnal pattern in diet selection, which has been explained by a desire to eat rapidly during the morning meal and avoidance of having to graze during the night. When sheep were given a choice between adjacent patches of clover and grass, they showed the greatest preference for clover in the morning and ate more grass and less clover during the evening meal $[37,43]$. In the same way, when sheep had the choice between adjacent vegetative and reproductive patches, they spent more time grazing the reproductive patch during the evening meal [15].

\subsubsection{Dietary experiences}

Dietary experiences, particularly early in life, modulate foraging behaviour and diet selection [48]. For example, naive ruminants may eat up to $40 \%$ less than experienced animals in the same environment, even when they graze for up to $20 \%$ longer [49]. When foraging, animals adapt to their environment, by developing their ability to recognise and consume the vegetation $[12$, 18 ] together with learning and memorising the distribution of resources. Learning from the dam and social partners [59], and recognition of post-ingestive consequences of diet choices play an important role in this adaptation and in the acquisition of appropriate dietary habits. Lambs accustomed to graze either clover or grass with their dam have a stronger post-weaning preference for the species they had previously experienced [51]. After weaning, kids reared by ewes spent more time eating clover than those reared by goats, consistent with a stronger preference for clover of ewes compared with goats [40].

For adults, short-term neophilia may temporarily modulate preferences. Sheep that had grazed either clover or grass swards for 3 weeks subsequently showed a stronger preference for the species previously lacking in their diet; however, after 3 days, they reverted to a stronger preference for the species they were previously accustomed to [43].

\subsubsection{Social environment}

The influence of social environment on foraging decisions has as yet received little attention. Foraging within a group may present advantages, such as deriving benefit from experiences of conspecifics or minimising risks of predation. Scott et al. [54] observed that, when selecting a patch in a new environment, lambs relied more on the location of their conspecifics than on their own dietary experiences, whereas the opposite effect was observed in a familiar environment. Social environment may also present constraints because of competition for food or hierarchical position in the herd. For example, impala (Aepyceros nelampus) were observed to select bushes according to the number of animals foraging in the group, as well as the available biomass of leaves [20]. Thouless [60] observed that the intake of subordinate red deer was affected by breaks in grazing due to scanning/avoiding dominant animals.

\subsubsection{Individual variation}

There may be large inter-individual variability in foraging decisions. Animals that are less selective prefer greater intake rate to the detriment of the quality of the diet, whereas animals that are more selective favour quality of the diet but suffer a penalty to intake rate [47]. Amplitude of individual variability is not well known, nor is its degree of repeatability or its origin, but its importance demonstrates plasticity of foraging behaviours and the different trade-offs an animal can make between different behavioural options. 


\section{CONCLUSIONS}

Intake, diet composition and the impact of grazing on the vegetation is the result of a complex interaction between the animal and the vegetation. The animal's morphological characteristics partly determine foraging behaviour and diet selection and largely explain between-species dietary differences. When considering the practical objective of resource management, animal species may differ in their effect on vegetation. Horses and cattle may have a greater ability to control low-quality swards than sheep, whereas sheep prefer quality to quantity. More generally, because of between-species dietary differences, the scope for complementary grazing increases with vegetation heterogeneity.

Through selective grazing, the animal selects a diet of higher nutrient quality than that on offer, and distributes its impact on the environment. Nevertheless, the determinants of foraging decisions remain obscure and a matter of debate. The complexity of animal/vegetation interactions has led to the development of experimental situations (short-term, simple dietary choices) to test hypotheses. In this case, animals tend to maximise their rate of food intake. However, short-term predictions of foraging behaviour are not sufficiently validated at a daily scale basis, which may be additionally affected by digestive constraints, balance of nutrients, diurnal pattern of selection and sampling. Intake prediction is further impaired by a poor ability to predict grazing time. General understanding of diet selection may, nevertheless, be sufficient to predict switches from grazing preferred to less-preferred patches, and reduce further decline in sward quality. Predicting diet selection is further complicated in more complex situations with searching constraints, making the environment more difficult for the animal to perceive.

Initially, experiments and models focused on short-term foraging behaviour and diet selection. The challenge is now to integrate these to larger spatio-temporal scales. Further steps are needed: i) integration of digestive processes; ii) refinement of searching constraints and the animal's abilities to search for and learn about food distribution; and iii) integration of competing motivations such as shelter, social interactions and predator avoidance.

\section{REFERENCES}

[1] Bazely D.R., Foraging behaviour of sheep (Ovis aries $\mathbf{L}$.) grazing on swards of perennial ryegrass (Lolium perenne L.), Ph. D. thesis, Oxford University UK, 1988, $180 \mathrm{p}$.

[2] Black J.L., Kenney P.A., Factors affecting diet selection by sheep. II. Height and density of pasture, Aust. J. Agric. Res. 35 (1984) 565-578.

[3] Burlison A.J., Hodgson J., Illius A.W., Sward canopy structure and the bite dimensions and bite weight of grazing sheep, Grass Forage Sci. 46 (1991) 29-38.

[4] Carrère P., Louault F., Soussana J.F., Pichon P. Defoliation of a grass (Lolium perenne L.) clover (Trifolium repens $\mathrm{L}$.) mixture continuously grazed by sheep, Vth Int. Rangeland Congress, 1995, pp. 80-81.

[5] Charnov E.L., Optimal foraging, the Marginal Value Theorem, Theor. Pop. Biol. 9 (1976) 129-136.

[6] Clark D.A., Harris P.S., Composition of the diet of sheep grazing swards of differing white clover content and spatial distribution, N. Z. J. Agr. Res. 28 (1985) 233-240.

[7] Clarke J.L., Welch D., Gordon I.J., The influence of vegetation pattern on the grazing of heather moorland by red deer and sheep, I. The location of animals on grass/heather mosaics, J. Appl. Ecol. 32 (1995) 166-176.

[8] Demment M.W., Greenwood G.B., Forage ingestion: effects of sward characteristics and body size, J. Anim. Sci. 66 (1988) 2380-2392.

[9] Demment M.W., Van Soest P.J., A nutritional explanation for body-size patterns of ruminant and non-ruminant herbivores, Am. Nat. 125 (1985) 641-672.

[10] Demment M.W., Distel R.A., Griggs T.C., Laca E.A., Deo G.P., Selective behaviour of cattle grazing ryegrass swards with horizontal heterogeneity in patch height and bulk density, Proc. XVII Inter. Grass. Congress, 1993, pp. 712-714.

[11] Demment M.W., Peyraud J.L., Laca E.A., Herbage intake at grazing: a modelling approach, in: Journet M., Grenet E., Farce M.H., Thériez M., Demarquilly C., (Eds.), Recent Development in the Nutrition of Herbivores, Inra, Versailles, 1995, pp. 121-141. 
[12] Distel R.A., Villalba J.J., Laborde H.E., Effects of early experience on voluntary intake of lowquality roughage by sheep, J. Anim. Sci. 72 (1994) 1191-1195.

[13] Distel R.A., Laca E.A., Griggs T.C., Demment M.W., Patch selection by cattle: maximisation of intake rate in horizontally heterogeneous pastures, Appl. Anim. Behav. Sci. 45 (1995) 11-21.

[14] Dulphy J.P., Jouany J.P., Martin-Rosset W., Theriez M., Aptitudes comparées de différentes espèces d'herbivores domestiques à ingérer et digérer des fourrages distribués à l'auge, Ann. Zootech. 43 (1994) 11-32

[15] Dumont B., Petit M., D'Hour P., Choice of sheep and cattle between vegetative and reproductive cocksfoot patches, Appl. Anim. Behav. Sci. 43 (1995) 1-15.

[16] Edwards G.R., Newman J.A., Parsons A.J., Krebs J.R., The use of spatial memory by grazing animals to locate food patches in spatially heterogeneous environments: an example with sheep, Appl. Anim. Behav. Sci. 50 (1996) 147-160.

[17] Edwards G.R., Newman J.A., Parsons A.J., Krebs J.R., Use of cues by grazing animals to locate food patches: an example with sheep, Appl. Anim. Behav. Sci. 51 (1997) 59-68.

[18] Flores E.R., Provenza F.D., Balph D.F., Role of experience in the development of foraging skills of lambs browsing the shrub serviceberry, Appl. Anim. Behav. Sci. 23 (1989) 271-278.

[19] Flores E.R., Laca E.A., Griggs T.C., Demment M.W., Sward height and vertical morphological differentiation determine cattle bite dimensions, Agron. J. 85 (1993) 527-532.

[20] Fritz H., De Garine-Wichatitsky M., Foraging in a social antelope: effects of group size on foraging choices and resource perception in impala, J. Anim. Ecol. 65 (1996) 736-742.

[21] Gordon I.J., Illius A.W., Incisor arcade structure and diet selection in ruminants, Funct. Ecol. 2 (1988) 15-22.

[22] Gordon I.J., Illius A.W., Milne J.D., Sources of variation in the foraging efficiency of grazing ruminants, Funct. Ecol. 10 (1996) 219-226.

[23] Gordon I.J., Illius A.W., Intake and diet selection by sheep grazing grass/clover patches, Proc. XVII Int. Grassl. Cong., 1997, pp. 15-3, 15-4.

[24] Grant S.A., Suckling D.E., Smith H.K., Torvel L., Forbes T.D.A., Hodgson J., Comparative studies of diet selection by sheep and cattle: the hill grasslands, J. Ecol. 73 (1985) 987-1004.

[25] Harvey A., Orr R.J., Dietary preference of sheep for grass and clover at contrasting sward suface heights, Br. Soc. Anim. Sci. Winter Meeting, 1996, pp. 161.

[26] Illius A.W., Allometry of food intake and grazing behaviour with body size in cattle, J. Agric. Sci. Camb. 113 (1989) 259-266.
[27] Illius A.W., Gordon I.J., The allometry of food intake in grazing ruminants, J. Anim. Ecol. 56 (1987) 989-999.

[28] Illius A.W., Gordon I.J., Diet selection in mammalian herbivores - constraints and tactics, in: Hughes R.N. (Ed.), Diet selection, Blackwell Scientific Publications, Oxford, 1993, pp. 157-181.

[29] Illius A.W., Hodgson J., Progress in understanding the ecology and management of grazing systems, in: Hodgson J., Illius A.W. (Eds.), The Ecology and Management of Grazing Systems, CAB International, 1996, pp. 429-458.

[30] Illius A.W., Gordon I.J., Elston D.A., Milne J.D., Diet selection in grazing ruminants: A test of rate maximisation, Ecology (1998), in press.

[31] Jamieson W.S., Hodgson J., The effects of variation in sward characteristics upon the ingestive behaviour and herbage intake of calves and lambs under a continuous stocking management, Grass Forage Sci. 34 (1979) 273-282.

[32] Krebs J.R., McCleery R.H., Optimisation in behavioural ecology, in: Krebs J.R., Davies N.B. (Eds.), Behavioural Ecology: An Evolutionary Approach, Sinauer Associates, Sunderland, Massachusetts, 1984, pp. 91-121.

[33] Laca E.A., Demment M.W., Foraging strategies of grazing animals, in: Hodgson J., Illius A.W. (Eds.), The Ecology and Management of Grazing Systems, CAB International, 1996 , pp. 137-157.

[34] Laca E.A., Ortega I.M., Integrating foraging mechanisms across spatial and temporal scales, Vth Int. Rangeland Congress, 1995, pp. 129-132.

[35] Laca E.A., Ungar E.D., Seligman N., Demment M.W., Effects of sward height and bulk density on bite dimensions of cattle grazing homogeneous swards, Grass Forage Sci. 47 (1992) 91-102.

[36] Laca E.A., Distel R.A., Griggs T.C., Deo G., Demment M.W., Field test of optimal foraging with cattle: the marginal value theorem successfully predicts patch selection and utilisation, Proc. XVII Inter. Grassl. Congress, 1993, pp. 709-710.

[37] Newman J.A., Penning P.D., Parsons A.J., Harvey A., Orr R.J., Fasting affects intake behaviour and diet preference of grazing sheep, Anim. Behav. 47 (1994) 185-193.

[38] Newman J.A., Parsons A.J., Penning P.D., A note on the behavioural strategies used by grazing animals to alter their intake rates, Grass Forage Sci. 49 (1994) 502-505.

[39] Newman J.A., Parsons A.J., Thornley J.H.M., Penning P.D., Krebs J.R., Optimal diet selection by a generalist grazing herbivore, Funct. Ecol. 9 (1995) 255-268.

[40] Orr R.J., Penning P.D., Parsons A.J., Harvey A, Newman J.A., The role of learning and experience in the development of dietary choice by sheep and goats, Ann. Zootech. 44 (1995) 111. 
14!] Orr R.J., Harvey A., Kelly C.L., Penning P.D., Bite dimensions and grazing severity for cattle and sheep, in: Proceedings Fifth Research Conference, British Grassland Society, Seale Hayne Faculty of Agriculture, Food and Land Use University of Plymouth, 8-10 September, 1997. pp. 185-186.

142] Parsons A.J.. Thornley J.H.M., Newman J., Penning P.D., A mechanistic model of some physical determinants of intake rate and diet selection in a two-species temperate grassland sward, Funct. Ecol. 8 (1994) ] 87-204.

[43] Parsons A.J., Newman J.A., Penning P.D., Harvey A., Orr R.J., Diet preference of sheep: effects of recent diet, physiological state and species abundance, J. Anim. Ecol. 63 (1994) 465-478.

1441 Prache S., Intake rate, intake per bite and time per bite of lactating ewes on vegetative and reproductive swards, Appl. Anim. Behav. Sci. 52 (1997) 53-64.

145] Prache S., Peyraud J.L.. Préhensibilité de l'herbe pâturée chez les bovins et les ovins, Inra Prod. Anim. 10 (1997) 377-390.

[46] Prache S., Roguet C., Louault F., Petit M., Évolution des choix alimentaires d'ovins entre talles végétatives et épićes au cours de l'exploitation d'un couvert épié de dactyle, Renc. Rech. Rumi* nants 3 (1996) 89-92.

[47] Prache S., Roguet C., Petit M., How degree of selectivity modifies foraging behaviour of dry ewes on reprodutive compared to vegetative sward structure, Appl. Anim. Behav. Sci. 57 (1998) 91-108.

[48] Provenza F.D., Postingestive feedback as an elementary determinant of food preference and intake in ruminants, J. Range Manage. 48 (1995) $2-17$.

149| Provenza F.D., Balph D.F., Diet learning by domestic ruminants: theory, evidence and practical implications, Appl. Anim. Behav. Sci. 18 (1987) 211-232

[50] Provenza F.D., Balph D.F., Applicability of five diet-selection models to various foraging challenges ruminants encounter, Behav. Mech. Food Select. 20 (1990) $423-460$.

151] Ramos A., Tennessen T., Effect of previous grazing experience on the grazing behaviour of lambs, Appl. Anim. Behav. Sci. 33 (1992) $43-52$.

[52] Roguet C., Stratégie de pâturage des ovins à l'échelle de la station alimentaire : utilisation, déplacements, thèse INA-PG, 1997, I11 p.
[53] Roguet C., Prache S., Petit M., Feeding station behaviour of ewes in response to forage availability and sward phenological stage, Appl. Anim. Behav. Sci. 56 (1998) 187-201.

[54] Scotı C.B., Banner R.E., Provenza F.D., Observations of sheep foraging in familiar and unfamiliar environments: familiarity with the environment influences diet selection. Appl. Anim. Behav. Sci. 49 (1996) 165-171.

[55] Shipley L.A., Spalinger D.E., Influence of size and density of browse patches on intake rates and foraging decisions of young moose and white-tailed deer, Oecologia 104 (1995) 1!2-121.

156] Shipley L.A., Gross J.E.. Spalinger D.E.. Hobbs N.T., Wunder B.A., The scaling of intake rate in mammalian herbivores, Am. Nat. 143 (1994) 1055-1082.

[57] Spalinger D.E., Hobbs N.T., Mechanisms of foraging in mammalian herbivores: new models of functional response, Am. Nat. 140 (1992) $325-348$.

[58] Taylor C.S., Murray J.L., Illius A.W., Relative growth of incisor arcade breath and eating rate in cattle and sheep. Anim. Prod. 45 (1987) $453-458$.

[59] Thorhallsdottir A.G., Provenza F.D., Balph D.F., Ability of lambs to learn about novel foods while observing or participating with social models. Appl. Anim. Behav. Sci. 25 (1990) 25-33.

[60] Thouless C.R., Feeding competition between grazing red deer hinds, Anim. Behav. 40 (1990) $105-111$.

[6!] Ungar E.D.. Ingestive behaviour, in: Hodgson J. Illius A.W. (Eds.). The ccology and management of grazing systems, CAB International, 1996, pp. 185-218.

[62] Wallis de Vries M.F., Effects of resource distribution patterns on ungulate foraging behaviour: a modelling approach, Forest Ecol. Manag. (1996) 167-177.

163] Wallis de Vries M.F., Schippers P.. Foraging in a landscape mosaic: selection for energy and minerals in free-ranging cattle, Oecologia 100 (1994) 107-117

|64| Ward D., The role of satisficing in foraging theory, Oikos 63 (1992) 312-317.

165| Wilmshurst J.F., Fryxell J.M., Hudson R.J., Forage quality and patch choice by wapiti (Cervus elcphus), Behav. Ecol. 6(1995) 209-217. 